\title{
Ritual and Diplomacy: The 200-Years Crisis in Relation between Parhae and Silla
}

\author{
Alexander A. Kim \\ Faculty of history, Ussuriysk State Pedagogic institute \\ 692000, Russian Federation, t. Ussuriysk, Nekrasova St. 35, Russia \\ Tel: 7-4234-346787 E-mail: kimaa9@gmail.com
}

\begin{abstract}
The state of Parhae (in Chinese reading- Bohai) existed in what is now Russian Maritime region, North Korea and Northeastern China from the late $7^{\text {th }}$ to the early $10^{\text {th }}$ centuries AD. Parhae played a major role at relations between Silla, Japan and Chinese empire Tang. Of course, Parhae was subjected to important cultural influence from other countries and in some cases followed their ritual and diplomatic tradition. Many specialists from Japan, Russia, China and both Korean states have done research of different aspects of Parhae history and culture. However, many scholars have not paid attention to influence of ritual system at international relation of Parhae.

In opinion of author, Parhae and Silla had antagonistic relation during 200 years because they could not agree about their respective vis-à-vis status each other. For example, Silla did not want to recognize Parhae as a sovereign state, which by recognized and independence state from China, but Silla was vassal of empire Tang.

This article critically analyzes relation between Parhae and Silla for of the origin of conflict of between countries using Russian and Korean materials (materials by South and North Korean works).

Keywords: History, Parhae (Bohai), Silla, Korea, Khitan

\section{Situation before establishment of Bohai state and earliest periods of Bohai and Silla relations}

Parhae (in Chinese and Russian readings - Bohai, in Japanese reading- Bokkai) can be seen as a first state which existed in what is now Russian Far East, and this alone makes Parhae historically important. This state was founded in 698 AD and collapsed in 926 AD. It occupied in the areas now known as Manchuria, Russian Maritime Province and part of North Korea.
\end{abstract}

\subsection{Establishment Bohai}

According to the Japanese annals, the Parhae state was founded in 698 AD (according to a several Korean materials Parhae was established in 699 , but almost Korean scholars prefer to use date from the Japanese materials). (Note 1) However, before 698 many events influenced the formation of this state. In the line of Parhae's power build-up, the Korean kingdom Koguryo was destroyed in 668 by the Tang empire and Silla kingdom and parts of the Mohe (in Korean reading - Malgal) tribes, who had been vassals of Koguryo, loose much power and influence and switched their loyalty to the empire of Tang.

The Mohe people and Koguryo population, who lived at territory of Mohe tribes, however, refused the pressure from Tang China and carefully prepared for a rebellion. Short-sighted politics of Tang also provoked a rebellion by Khitan (in Korean reading - Korran) tribes in 696 and the Mohe along with Koguryo groups used this as a pretext to establish the new state of Jin (Zhen). The king of new state was Dae Jo-yǒng (in Chinese reading -Da Zuorong). He destroyed Chinese army, which pursued him, and built several castles. After establishment of Jin he established relations with Turkic tribes and Silla, who had antagonistic relations with China. In 713 he received Tang recognition as ruler of the new state called Parhae. From this date on we can find Parhae mentioned in Chinese texts.

\subsection{Policy of Bohai after 733}

Parhae launched trade and political relations with Tang and Japan, ties, however, that never got on to a peaceful footing. In reign by second rule Dae Mu-ye, in 732 Parhae started a war against China and the Parhae navy attacked the Shandong peninsula. Parhae's army also assisted the Khitans, who were fighting with the Tang. In this difficult situation the Tang began mobilizing all army and along with the Silla army built up an alliance consisting of several tribes thus 
forming a phalanx that could march against Parhae. While Silla initially attacked unsuccessfully,(Note 2) the two-pronged pressure from two fronts finally resulted in Parhae having to ask for a peace accord with China in 733.

Parhae's third ruler Dae Hǔm-mu (in Chinese reading- Da Jin-mao) (737-793) is usually considered to be one of its most influential leaders who led Parhae into a powerful state. (Note 3) In the period of his reign, Parhae received the prestigious kingdom status from the Tang dynasty, developed relations with China and Japan, strategize an alliance with Japan against Silla, and tried to introduce Parhae as an empire that could influence the Tang. (Note 4)

The relatively advanced state of development of the Parhae kingdom can also be gleaned from the following circumstances. In Japanese and Tang annals we find references to Parhae students who studied in China and with Silla students passed the state exams for foreign students. Also there were highly qualified Parhae scholars who became famous for their works in Japan. During this time many Parhae ships frequented Japanese ports for trade through which contacts could be multiplied with many tribes in Northeastern Asia. And it should be noted that the Parhae territory consisted of five capitals, just as Tang China, 15 provinces and 62 districts.

However after King Dae Hŭm-mu Parhae experienced a political crisis, the kingship changed hands a number of times. Perhaps during this period Parhae lost several provinces, because the Mohe tribes, who lived at the periphery of Parhae's state borders, rebelled. Among the outstanding personages of the $8{ }^{\text {th }} \mathrm{C}$. count the distinguished Parhae kings Dae In-su (in Chinese reading -Da Ren-xiu) (819-830) and Dae I-Jin (in Chinese reading - Da Yi-zhen) (830-857), who again faced conquest by independent Mohe tribes. (Note 5)

\subsection{Bohai destruction}

At the end of the $8^{\text {th }} \mathrm{C}$. the Khitans began wars against other tribes who lived near them. Khitan chiefs also fielded their chances to battle China, because in 906 the Tang Empire collapsed while several regional successor kingdoms were fighting each other. However, before conquering China, the Khitans had to destroy the Parhae in the east in order to avoid a Parhae attack on Khitan from the rear. Therefore the Khitans started a war with Parhae. For 20 years the Parhae and Khitans were enmeshed in a tough battle, but due to the Khitan's effective cavalry and Khitans destroyed Parhae eventually in 926. (Note 6)

From 926 onward the Parhae people lost their state, but could never forget its grandeur and thus in 929-930 and again in 1115-116 rebelled for reestablish Parhae, but unsuccessfully. Importantly however, the Parhae people played a considerable role in the establishment and maintenance of Khitan's successive administrative systems of the Khitan empire of Liao (in Korean reading - Yonara), Jurchen empire Jin (in Korean reading- Gŭm nara) and the Northern Sung. (Note 7)

\section{The study of relations between Bohai and Silla}

In recent decades, scholars of South and North Koreas, Russia, Japan and China have paid much attention to Parhae history and culture. Nonetheless, because of scarcity of materials some important parts of Parhae history still remain unknown.

Among those problems one should mention the history of hostile relations which existed between Parhae and Silla, a state which in the same period occupied southern and central parts of Korean peninsula. In recent years Korean scholars began to pay special attention to this problem, which might reflect the current trend of the Korean historiography whose adherents hope to prove that Parhae was biggest "Korean" state of the period. Hence, the historiography tends to present the period of Silla - Parhae coexistence in Korea Peninsula as a "period of South and North States" in Korean history. (Note 8)

However, many Korean scholars are often in trouble when explaining hostile relations between those states during more than two centuries of their history. This hostility is more remarkable because at the early stage political contacts of Parhae and Silla were friendly.

The research is made difficult by absence of Parhae texts, so all scholars have to rely one Chinese, Japanese and Korean texts.

Soviet-Russian, Chinese and Japanese studies of East Asia have not paid much attention to this problem, while traditionally many Korean scholars believe that conflict between Silla and Parhae began from mutual territorial claims. (Note 9) So, Han Gju-chǒl wrote that though relations between both states were hostile during 200 years, in early period Silla and Parhae did not differ much in social and cultural aspects. But during 200 years of conflicts between those states contradictions went deep and initial unity in cultural and historical aspects was forgotten. This, according to Han Gju-chǒl, became the reason why Silla helped the Khitans to destroy Parhae. (Note 10)

\subsection{Earliest period of the relations between Bohai and Silla}

Therefore we need to consider in some detail political events of the early 8th century. A new state was established in 698, and from 713 it changed name to Parhae. Parhae sent ambassador to Silla for establish diplomatic relations. In 700 
Silla sent an ambassador to Parhae ruler Dae Jo-yǒng. Dae Jo-yǒng was given a high official rank - the fifth rank of "Dae achan". (Note 11)

Thus on the early stage the relations between Silla and Parhae were friendly, probably due to their shared hostility to Tang.

However in 713 Silla has constructed several forts on border with Parhae. (Note 12) So we can surmise that at this period (700-713) relations between Parhae and Silla became tense.

While considering this period we can assume that reason of hostile relations between both countries were not territorial claims by Parhae or Silla, but rather problem of relative status of both states. The crisis was triggered by Dae Jo-yǒng's decision to accept an official rank bestowed by Tang.

What is a fifth rank (Dae achan) of Silla, which was granted to Dae Jo-yǒng? The rank indicated a high position, but it was still position of a mere official at the service of Silla. So we can see that Silla recognized new state only under condition of its accepting vassal status from Silla (needless to say, the inferior status could be mere formality).

In order to understand the action of the Parhae ruler we should consider the situation around new state. Having established the state, Dae Jo-yǒng found himself in search of allies. In spite of his victory in battle against Tang army, he expected a prolonged war with China, but he had neither sufficiently big army nor economic conditions suitable for a fight with such a powerful enemy. At that time Silla also had a confrontation with Tang, because this Korean state had expelled Chinese army from Korean Peninsula's area after destroying Koguryo. (Note 13) This army of Tang came to help to Silla to destroy of Koguryo and Peakche (another Korean state, which was fight against Silla). Therefore Silla wanted alliance with Dae Jo-yǒng, maybe, having plan for use Bohai as buffer state against aggressive policy of China. So as Dae Jo-yǒng did not have a big power in military and economic aspects (according by Chinese annals, new state had about 100 thousands warriors and same number of families (Note 14)), Silla imposed vassal status to Dae Jo-yǒng.

How we can see, the reception of vassal status from Silla was necessary for continuing existence of Parhae state. Except for that Dae Jo-yǒng send ambassadors to the Turkic for ask about same support.

But in the following 13 years Parhae changed much. Dae Jo-yǒng used peace time very effectively. We don't have many materials about that period, but can see information which indicates that of power in his state increased. He subdued many tribes, who lived in adjacent areas and increased army and territory of Jin. Most likely, Dae Jo-yǒng looked for way to get rid of Silla's burdensome protection (even nominally), evidence of it we can see in following activity.

In 705 in Chinese imperial power was change and emperor cardinally corrected foreign policy of Tang. Therefore China sent ambassador to Parhae. The ambassador's task was to pacify Bohai As answer Dae Jo-yǒng sent his second son, Dae Mun-ye, as a hostage to Empire Tang. (Note 15)

That activity of Parhae ruler clearly demonstrated two things. On the one hand it was a great importance with was attached to relations with China for Parhae, while on the other hand it showed of Dae Jo-yǒng to get rid Silla's protection. Tellingly, Dae Jo-yǒng did not sent relatives as hostage to Silla.

System of receiving aristocratic hostages from other states and tribes was very popular in Empire Tang. This system guaranteed loyalty from those states and tribes, but on the other side hostages received chances to learn about Chinese political and military system and sometimes were engaged in espionage in China on behalf of their countries. (Note 16)

As result of ambassador's exchanges between Empire Tang and Parhae, Dae Jo-yǒng received new title "Parhaegunwang" of sovereign of Parhae. On one hand, it meant guarantee of peaceful co-existence with China, but it also launched antagonistic relations with Silla.

\subsection{The start of the antagonistic relations between Bohai and Silla}

As we can see, appointment of 713 from Empire Tang to Parhae completely cancelled appointment of Silla in 700 . Parhae became vassal of China like Silla and from this time didn't receive investiture from Silla. Of course, Silla leaders were not happy about such turn of events, but they did not send an army and didn't undertake any retaliation activity since Parhae was vassal of Tang and have 100 thousands soldiers. However Silla began to build fortifications on border with Parhae in 713 and 724. (Note 17) It demonstrates that during 13 years Parhae established strong army which probably surpassed army of its southern neighbor.

The growth of Parhae power, apparently, caused a lot of anxiety in Silla. Most likely, Silla was afraid a joint attack by from Tang and Parhae. Recent vassal of Silla, apparently, actively expanded to the south. Evidence of it we can see in following war between Empire Tang and Parhae 732-733, when Parhae fleet has gone from Amnok river (in ChineseYalu river) for attack Chinese seaport in Shandong peninsula. (Note 18) This fact clearly demonstrated that Parhae controlled areas, which earlier had been ruled by Silla, because after collapse of Koguryo this area had been given to Silla. This success Parhae could achieve only through military methods.

Chinese scholars considered another episode. In their opinions, Parhae must have a big number of warships for an 
attack in Shandong peninsula. (Note 19) However Parhae could not establish and fast develop shipbuilding industry in period of second Parhae ruler Dae Mu-ae, therefore we must think that it began of this building during the rule of Dae Jo-yǒng. It's demonstrated again activity of first Parhae ruler, but made question why Dae Jo-yǒng established fleet, he had problem with empire Tang and didn't need sea ships. Maybe he assumed in future conflict with Silla.

\subsubsection{Bohai relations of Dae Mu-ye}

Those antagonistic relations between Parhae and Silla contradict all foreign policy of second Parhae ruler Dae Mu-ye (in Chinese reading - Da Wuyi) who was looking for allies for fight against Empire Tang. For example, he developed relations with Khitan and Turkic tribes and Japan and aspired to receive support against China. Until 732 Silla has antagonistic relations with Tang and from 713 became hostile to Parhae. The reason of this paradoxical situation can was only one- claims of Parhae ruler in regard of his status. In spite of Parhae received investiture from China, Silla interpreted Bohai as barbarian country. Fact, that Parhae yet not Silla vassal, was very unpleasant for Silla`s king and aristocracy.

In opinion of North Korean scholars, Silla saw Parhae as a state of Koguryo people, and was afraid of it so much that wanted an alliance with China against such a formidable enemy. (Note 20)

Therefore, in war between Tang and Parhae in 732-733, Silla helped China, described Parhae as "rebelled barbarians" (Note 21) and improved relations with Tang. China asked Silla for military help and Silla sent army for "attack from both flanks" with warriors by empire Tang, who must separately from Silla attack Parhae in the north. However snow and rough mountain roads destroy this plan, Silla army loose half of its soldiers and come back to south.(Note 22) In spite of failure of Silla's expedition, this act exert of influence to war between Tang and Parhae. Silla show that can help China and Parhae must noted possibility of attack from south border.

After this war China formally gave to Silla the lands located to the south from the Phae river (modern Taedong river). (Note 23) We don't know who lived in those areas, but result of this diplomatic act of Tang led to a continued conflict between Silla and Parhae, because Parhae, most likely, also had interest to those territories.

\subsubsection{Bohai and Silla relation after war 732-733}

Parhae aspired status, actively competed with Silla in Empire Tang. In 7 month 798 Parhae ambassador arrived in China and ask about place above that place of Silla ambassador. (Note 24)

However Tang has given up, explained this decision by impossibility to change order, therefore Silla sent to Tang emperor an official letter "Grateful report to Emperor for proscription of North state occupied more high place". It says the following: "As known about origin of Parhae people, when Gouli (Koguryo) yet not destroyed, they [Parhae people] were the useless tribe of Mohe, same tribes were many, it name was that of small barbarian nation Sumo, and past [this tribe], being in competition with Gouli, moved to inner area [China]. (Note 25)

Those understandings of Silla rulers about Parhae as their vassal state can give information why in Silla official documents absence materials about ambassador's missions from Silla to Parhae - official historiography of Silla can't recognize send ambassadors to "vassal". Information about ambassador's missions do not exact, so as written about two ambassadors (Paek O (rank "Ilgilchan" in 790 and Sung Jǒng (rank "Kŭpchan") in 812) who sent to a "Northern state", but we don't know, whether this "Northern State" was Parhae, information about diplomatic contacts between Parhae and Silla in 10 C. received from Non-Korean materials. (Note 26) In spite of from 713 situation was changed, and Parhae and Silla were vassals of Empire Tang (but Silla dependency on China was greater than that of Parhae), Silla did not want to accept understanding Parhae as an equal state.

There are no doubts, that Parhae and Silla constantly competed each other. As it has been mentioned above, Silla participated in war between Parhae and Empire Tang and followed an for order from China to dispatch and army for an attack southern borders of Parhae state. But because of strong snowfall and mountain ways half of Silla army was lost and Silla army comes back to their country. And Parhae people had plan joint with Japan for an attack against Silla. (Note 27)

\subsubsection{Plan of joint attack Parhae and Japan against Silla}

Plan of joint attack Parhae and Japan against Silla established by Japan after incident in which Silla king Gyǒngdǒkkwang offended Japanese ambassadors in 758, refusing to meet with them. (Note 28) Before this episode, in 753, Silla king received the Japanese ambassadors, but treated them arrogantly and roughly. However, in opinion of South Korean scholar Han Gju-chǒl, main reason of plan of attack against Silla was a political crisis in Japan, therefore Japanese elite looked for decision of this problem in foreign expansion. (Note 29) And Han Gju-chŏl believes that this plan began to develop before the incident of 758. (Note 30)

After the incident of 758 Japan asked to Parhae about a joint attack Silla, so as didn't have jumping of place for attack of Silla. But Japan must revenge for political offence inflicted on the Japanese ambassadors. Parhae agreed of 
participate in this plan, maybe, considering it as punishment for the help which Silla had furnished to China during the war of 732-733.

In the 750-760 s. Parhae and Japan several times exchanged ambassadors whose tasks were to correct this plan. Most likely, Silla received information about this plan, because in the summer 762 Silla army built six castles in Parhae border. (Note 31)

As we can see, Silla was afraid of an attack by Parhae army, successfully fight with China in 732-733. But we don't see information about activities by Silla army for defense against Japan. Likely, Silla leaders were aware of the political situation and received information about domestic problems in Japan. Maybe, Silla king Gyǒngdǒkkwang understood this situation and therefore deliberately provoked Japanese ambassadors in 753 and 758. But China didn't like that conflict therefore Tang empire was making efforts to stop this conflict by diplomatic methods.

At that time Japan prepared fleet for landing in Silla territory and established "army of clear land" (Note 32) for colonization of south part of Silla. This plan of occupation new areas by Japan was not realized, but relations between Parhae and Silla were still antagonistic. But this Silla understanding about Parhae was reason why in Silla documents there are no information about diplomatic and trade relation with neighbor Parhae state.

Parhae had a "way to Silla" and 38 stations along this way. (Note 33) This seems to indicate understanding that Parhae and Silla maintained active relations, but in Silla's official documents we can find references about only two ambassadorial missions to "Northern State", but don't know what is "Northern state" means, and whether it was Parhae or some another country or tribe.

In Chinese and Japanese documents we can look for information about Parhae expansion before 732 and about "suppression" of Silla from Parhae in 818-820, (Note 34) as well as about participation of Silla soldiers in destruction of Parhae.

However in Silla documents we can't look for same information, maybe, Silla leaders wanted to present military conflicts with Parhae as fights against rebelling vassal.

Only for dates when Silla texts mention sending an army to the north provinces or building fortifications along the northern border we can surmise that it were episodes of political and military confrontations between Silla and Parhae, which were lost by Silla, and therefore not described in Silla`s official history.

\subsubsection{War between Bohai and Khitans}

Before attack Khitans to Parhae Silla had alliance with Parhae, but in 925 Silla broke an alliance pact with Parhae and helped to Khitans in their war against Parhae. We don't know about the scale of support provided by Silla army to Khitans. However, when after the victory in 926 Khitan ruler awarded warriors, who were good in fight against Parhae, among those warriors were soldiers from Silla. (Note 35) Therefore we can believe that this help was quite important for the Khitans. The reason of that actions of Silla to Parhae might have been in Silla's hostility to Parhae, which concentrated during 200 years of confrontation between Silla and Parhae and had its origin in problem of relative status between those states. We can surmise that because of this Silla saw Parhae only as its vassal, in Silla official histories remained silent on some important information about relations between Parhae and Silla, since this information contradicted the idea of Parhae's inferior status. This damaged out ability to research of Parhae history.

But from another side, Silla in relations with other states and tribes imitated of Tang, whenever impossible denying equal relations with other states and as result we can see absence of some important information in Silla's surviving foreign policy documents.

Except for that Silla didn't have possibilities similar to that of Tang and hence could not demonstrate big power, therefore imitation of Chinese system in foreign policy was reason of conflict with Parhae.

The North Korean scholars consider antagonistic relations between Parhae and Silla, think that Silla had renegade policy to Parhae, (Note 36) the South Korean historians believe that the base of conflict between Parhae and Silla were aggressive policy both states, Bohai want conquer south lands, but Silla - north lands. (Note 37) However specialists from both Korean states can not explain with deep arguments why friendly contacts of Bohai and Silla so fast changed to antagonistic relation, why Silla, which had antagonistic relation with Tang empire, helped to Chinese army against Parhae and etc. Almost all Russian scholars did not paid attention to that problem.

But, as we can see, consider and analysis relations Bohai and Silla across problem of the state's status can give understanding of many unclear episodes of Bohai and Silla history.

\section{The history of contacts between Parhae and Silla.}

698 - Dae Jo-yǒng sent ambassador to Silla.

700 - Silla sent an ambassador to Parhae ruler Dae Jo-yǒng. Dae Jo-yǒng was given a high official rank - the fifth rank of "Dae achan". 
713 - Silla built fortification on the border with Parhae.

721 - Silla mobilized 2000 peoples for support defense on the north border.

732-733 - war between Tang Empire and Parhae. Silla sent army for attack Parhae, but unsuccessful.

735 - China formally gave to Silla the land located to the south from the Phae river.

748 - Silla sent expedition for occupies south lands from Phae river.

758 - 762 - Parhae and Japan prepared fleet and army for attack Silla.

762 - Silla sent expedition for occupies south lands from Phae river.

762 - Silla support six castles on the border with Parhae.

781 - Silla sent expedition for occupies south lands from Phae river.

782 - Silla sent expedition for occupies south lands from Phae river.

790 - Silla sent ambassador Paek O (rank "Ilgilchan") to "Northern state".

812 - Silla sent ambassador Sung Jǒng (rank "Kǔpchan") to "Northern state".

818 - 820 - Parhae king Dae In-su won Silla at south.

826 - Silla mobilized 10 thousands peoples and built fortifications on the border with Parhae.

911 - security alliance between Parhae and Silla against Khitans.

925-926 - Silla helped Khitans at destroy Parhae state. Khitan imperator awarded Silla warriors.

\section{References}

\section{In Russian}

\section{На русском языке}

Gosudarstvo Bohaj i plemena Rossijskogo Dal nego Vostoka (The state Bohai (698-926) and Russian Far Eastern tribes). (1994). Moscow: Nauka.

Goncharov S.N. (1986). Kitajskaya srednevekovaya diplomatiya: otnosheniya mezhdu imperiyami Sun $i$ Czin'1127-1142 gg. (The China Middle Age's diplomacy: relations between empires Jin and Sung 1127-1142). Moscow: Nauka.

Ivliev A.L. (2005). Ocherk istorii Bohaya (The sketch of the Bohai history). Rossijskij Dal'nij Vostok $v$ drevnosti $i$ srednevekov'e: otkrytiya, problemy, gepotezy, Vladivostok: Dalnauka, pp .449 - 475.

Kozhanov S.T. (1980). Nachal'nyj period mezhdu imperiyami Sun i Czin` (1125-1127) (The first period of war between empires Sung and Jin (1125-1127)), Dal nij Vostok $i$ sosednie territorii v srednie veka. Istoriya i kul 'tura vostoka Azii. Novosibirsk: Nauka, pp. 39 - 48.

Matveev Z.N. (1929). Bohaj (Bohai). Vladivostok: Raboty Dal'nevostochnogo gosudarstvennogo universiteta. Seriya 6.

Samguk sagi. (1959). Vol.1. /translate by Pak M.N. Moscow: Nauka.

Ye Lunli. (1979). Istoriya gosudastva kidanej (The history of Khitan state (Cidan guoji)). Moscow : Nauka.

\section{In Korean}

\section{한국어}

Han Giu-chǒl. (1992). Koryǒaesǒ tonripundongkkaji parhaesa insik (The understandings about Parhae history from Koryo period to Movement for Independence), Yǒksabiphyǒn. Kaǔl, pp. 344-353.

Han Giu-chǒl. (1994). Parhaeǔi taekwankaesa (The history of Parhae foreign political relations). Seoul: Tosochulban sinsovon.

Han Giu-chǒl. (1999). Parhaesa yǒnguǔi hyǒnkwan kwa kwaje (The modern situation of Parhae history and subjects for study), Parhae kǒnguk 1300 chunyŏn (698-926). Seoul: Hakyǒnmunhwansa, pp. 15-36.

Jung Jin-hǒn. (1999). Parhaesa saryǒ wa parhaesa insikǔl pyǒnjeon koryǒsidaeǔi "Sase" sillin parhaekisarǔl junsimǔro (nonmun) (The historical materials of Parhae history and evolution of understandings about Parhae history- on the base of materials of "Sase", which published in Koryo period), Parhae kǒnguk 1300 chunyǒn (698-926). Seoul : Hakyǒnmunhwansa, pp.39-62.

Jang Kuk-jong. (2001). Parhaekuk kwa malgaljok (The Parhae state and Mohe tribes). -Seoul: Tosochulphan Jonsim.

Park Si-hyǒng. (2000). Parhaesa yǒngu wihayǒ (For study of Parhae history), Parhaesa yǒngu wihayǒ. - Seoul: Jongchi chulphan, pp. 7-68. 
Parhaesa (The history of Parhae). (1994). /redact. by Song Ki-ho, Han Gju-chǒl \& Lim Sang-sǒn. Hanguksa. k.10. Seoul.

Song Ki-ho. (1992). Parhae nambukhan-jung-il-roǔi jaguk jonsim haesok (The understanding about Parhae in Republic of Korea, People's Democratic Republic of Korea, China. Japan and Russia), Yǒksabiphyǒn. Kaǔl. pp. 333-343.

Song Ki-ho. (1995). Parhae jǒngchi yǒksa yǒngu (The study of Parhae political history), Seoul: Ilchokal.

Yu Dǔk-gong. (2000). Parhaego (The study of Parhae), Seoul: Hangukjonchǒnso

\section{Notes}

Note 1. Matveev 1929; Gosudarstvo Bohaj 1994.

Note 2. Samguksagi 1959.

Note 3. Gosudarstvo Bohaj 1994.

Note 4. Matveev 1929; Ivliev 2005: 459.

Note 5. Ivliev 2005.

Note 6. Ye Lunli 1979.

Note 7. Goncharov 1986; Kozhanov 1980.

Note 8. Song Ki-ho 1992: 334; Han Gju-chǒl 1992: 344; 1994: 9; 1999: 29; Jung Jin-hǒn 1999: 42.

Note 9. Han Gju-chǒl 1994.

Note 10. Han Gju-chǒl 1994: 135, Parhaesa 1996: 113.

Note 11. Han Gju-chǒl 1994; Parhaesa 1996: 101; Park Si-hyǒng 2000: 27.

Note 12. Parhaesa 1996: 101-102.

Note 13. Han Gju-chǒl 1994; Yu Dŭk-gong 2000: 51-52.

Note 14. Gosudarstvo Bohaj 1994.

Note 15. Parhaesa 1994: 29.

Note 16. Yu Dǔk-gong 2000: 52.

Note 17. Parhaesa 1994.

Note 18. Parhaesa 1994.

Note 19. Parhaesa 1994.

Note 20. Jang Kuk-jong 2001: 183-185.

Note 21. Samguksagi 1959: 219; Parhaesa 1994; Yu Dǔk-gong 2000: 54.

Note 22. Samguksagi 1959; Jang Kuk-jong 2001: 169.

Note 23. Parhaesa 1994: 34; Jung Jin-hǒn 1999: 49.

Note 24. Song Ki-ho 1995: 156.

Note 25. Ivliev 2005.

Note 26. Han Gju-chǒl 1994: 131-133.

Note 27. Han Gju-chǒl 1994.

Note 28. Parhaesa 1996: 104.

Note 29. Han Gju-chǒl 1994.

Note 30. Han Gju-chǒl 1994: 203-207.

Note 31. Han Gju-chǒl 1994: 206.

Note 32. Han Gju-chǒl 1994: 206; Parhaesa 1996: 104-130.

Note 33. Han Gju-chǒl 1994: 11; Song Ki-ho 1995: 18.

Note 34. Yu Dǔk-gong 2000: 64.

Note 35. Song Ki-ho 1995: 205-207, Ivliev 2005.

Note 36. Jang Kuk-jong 2001.

Note 37. Han Gju-chǒl 1994. 